\author{
F. M. Raimondo, V. Spadaro \& E. Di Gristina
}

\title{
Centaurea heywoodiana (Asteraceae), a new species from the Nebrodi Mountains (NE-Sicily)
}

\begin{abstract}
Raimondo, F. M., Spadaro, V. \& Di Gristina, E.: Centaurea heywoodiana (Asteraceae), a new species from the Nebrodi Mountains (NE-Sicily). — Fl. Medit. 30: 369-376. 2020. ISSN: 1120-4052 printed, 2240-4538 online.

A new endemic species of Centaurea is here described from the Nebrodi Mountains, in Sicily, and named Centaurea heywoodiana. Information on its morphology, distribution, ecology and taxonomic relationship is also provided.

Key words: endemism, Mediterranean flora, taxonomy, plant biodiversity, Nebrodi regional park, Italy.
\end{abstract}

\section{Introduction}

The native vascular flora of Sicily has been well explored in the past (Raimondo 1988) and the Sicilian territory is one of the well-known floristic territories among Italian and Mediterranean regions (Raimondo \& al. 2005). However, not all of the regional territory was investigated with the same in-depth level. There are still some areas that have on average explored by scholars and among these, there is the extensive mountain area of the Nebrodi Mountains. This area has become the subject of considerable study only in recent decades by botanists of Catania University and by scholars who work, or have worked, in the botanical institution of Palermo University. About this, please refer to the taxonomic investigations of Raimondo \& Schicchi (2004), Raimondo (2008), Marino \& al. (2012) and Brullo \& al. (2015).

Furthermore, investigations on new vegetation aspects of the same mountains allowed to acquire herbarium specimens, whose study provided us to identify a new taxon in the Asteraceae family. In this rich and complex family, some genera are still critical in Sicily, such as Anthemis L., Hieracium L., Pilosella Vaill., Taraxacum F. H. Wigg. and Centaurea L. Several taxa belonging to these genera have recently been described or rediscovery for the Sicilian flora: Anthemis pignattiorum (Guarino \& al. 2013); Hieracium pignattianum (Raimondo \& Di Gristina 2004), H. madoniense (Raimondo \& Di Gristina 2007), H. pallidum subsp. aetnense (Gottschlich \& al. 2013), H. hypochoeroides subsp. montis-scuderii 
(Di Gristina \& al. 2013), H. busambarense (Caldarella \& al. 2014), H. schmidtii subsp. nebrodense (Di Gristina \& al. 2016a); Pilosella hoppeana subsp. sicula (Di Gristina \& al. 2016b); Taraxacum garbarianum (Peruzzi \& al. 2009); Centaurea erycina (Raimondo \& Bancheva 2004), C. saccensis (Raimondo \& al. 2004), C. giardinae (Raimondo \& Spadaro 2006), C. sicana (Raimondo \& Spadaro 2008) and C. aegusae (Domina \& al. 2017). Recent is also the finding in the north-west of the island of Xeranthemum cylindraceum Sm. (Costa \& Di Gristina 2020).

The new taxon of the Nebrodi Mountains, described below, belongs to the genus Centaurea.

Centaurea heywoodiana Raimondo, Spadaro \& Di Gristina sp. nov. (Fig. 1)

Type - Holotypus: Sicilia: Monti Nebrodi, Floresta, pendici sud orientali di Monte Musarra, nei luoghi aperti pascolati, su suolo argilloso-calcareo, $1081 \mathrm{~m}$ (s.l.m.), $37^{\circ} 51^{\prime} 39,45^{\prime \prime} \mathrm{N}-14^{\circ} 54^{\circ} 28,94^{\prime \prime} \mathrm{E}, 27$ luglio 2020, Raimondo (PAL-Gr) - Isotypi in FI and PAL.

Diagnosis. - Planta perennis, caespitosa. Caulis obliquus, scaber, ramosus et praecipue bifidus ad apicem. Rami secundi ordinis ab primo dimidio caulis, etiam bifidi ad apicem. Folia viridi-glauca: folia rosularia pinnatisecta, folia caulina minora, pinnatifida vel hastata; folia apicis brevi, lineari, mucronata ad apicem. Capitula solitaria, minuta, numerosa; involucrum ovatum; bractae inferiores ovatae-lanceolatae; bractae medianae ventricosae; appendices leviter exsertae, brunneae, fimbriatae. Flosculi purpurei. Fructus glaber, brunneus, minutus, subcostatus, et in longitudinem striatus.

Description. - Perennial herbaceous plant, bushy, (20) 25-45 (50) cm high. Stems oblique, scabrid, branched and particularly bifurcated at the extremity (Fig. 2); secondorder branches starting from the first half of the scape, inserted perpendicularly or at a maximum of $45^{\circ}$, also bifurcated at the end. Leaves glaucous green; basal leaves pinnatisect 7-10 cm, with oblong-lanceolate segments; cauline leaves from pinnatifid to astate, and progressively smaller $(1.2-2 \mathrm{~cm})$; apical leaves linear-lanceolate $(0.5) 0.6-1(1.2) \mathrm{cm}$, mucronate at apex. Capitula solitary; involucre ovoid $(0,7) 0.8-1(1.1) \mathrm{cm}$ in diameter; lower bracts ovate-lanceolate, 5-7 × 3-4 mm; middle bracts ventricose, $8-10 \times 1.2-1.5$ $\mathrm{mm}$; appendages dark brown, slight exserted, with 5-7 fimbriae on each side. Florets purple. Achenes brownish, glabrescent, 3-3.5 mm, slightly costate, longitudinally striped; pappus $1 / 3$ long of the achene.

Biological form. - hemicryptophyte (H caesp).

Etymology. - The epithet of the name of the new Sicilian species recalls the surname of the illustrious Plant Scientis Vernon Hilton Heywood, professor emeritus of Botany at the University of Reading, co-editor of Flora Europaea, founding member of OPTIMA, and for many years, active component of the Executive Council of this Organization.

Phenology. - Flowering in July; fruiting from July to August. 


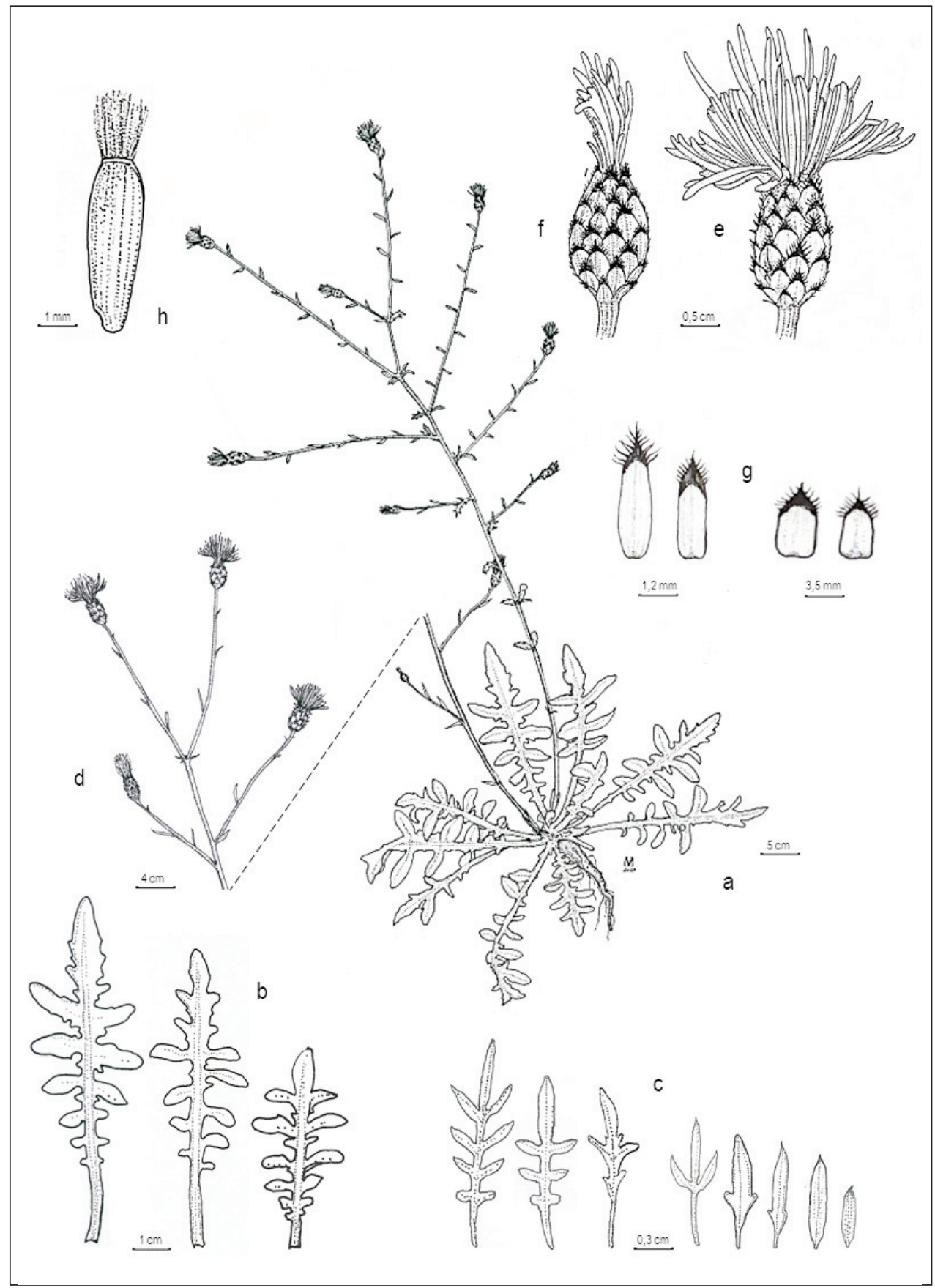

Fig. 1. Iconographic plate of Centaurea heywoodiana: a) plant; b) basal leaves; c) cauline (left) and apical leaves of the stem (right); d) particular of the bifurcated extremity of the stem; e) capitulum in flower; f) capitulum after flowering; g) exsternal bracts of the capitulum; h) mature achene with pappus. 


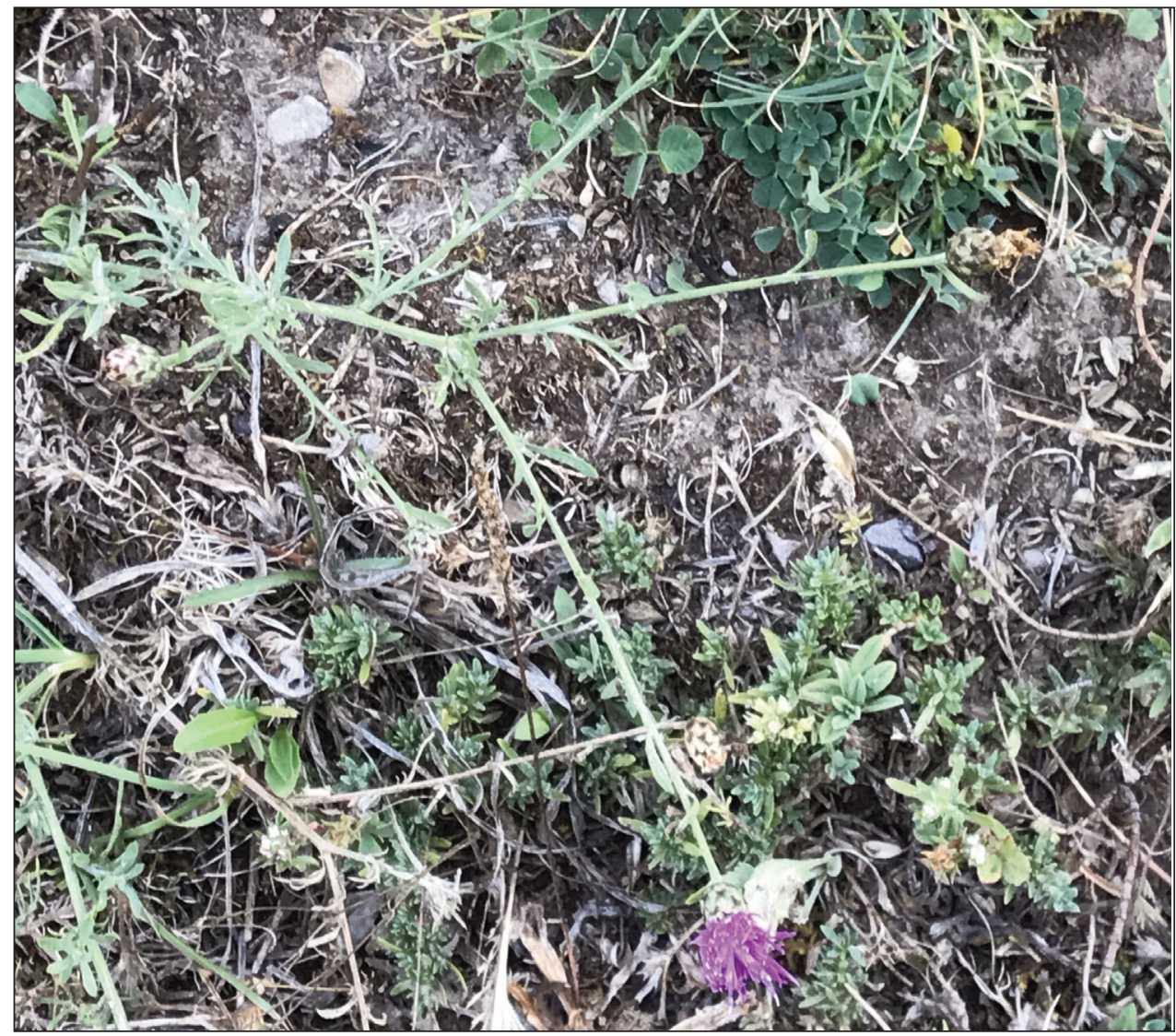

Fig. 2. Particular of the stem of Centaurea heywoodiana, branched and bifurcated at the extremity.

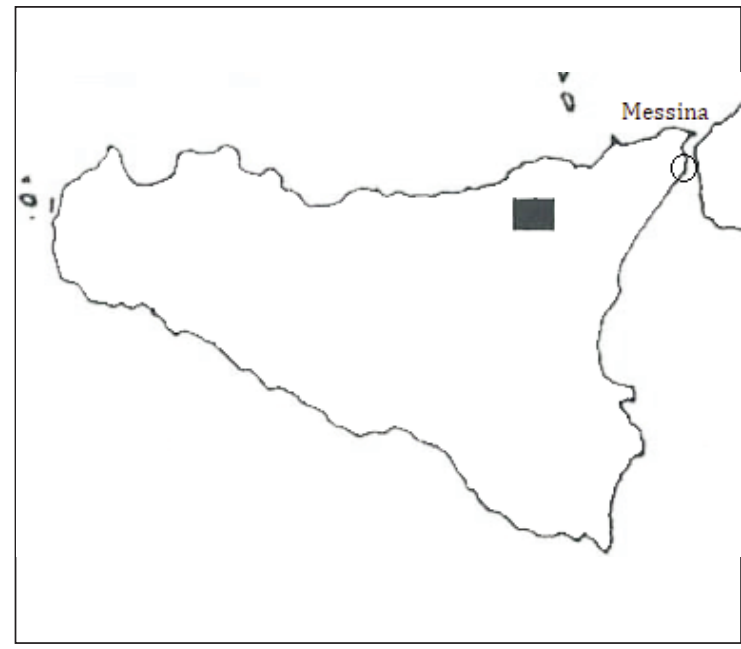

Fig. 3. Localization of the locus classicus of Centaurea heywoodiana in Sicily. 
Distribution and ecology. - Centaurea heywoodiana occurs in the eastern sector of the Upper Nebrodi Mountains (see Domina \& al. 2018), in Sicily (Fig. 3). As well as on the slopes of Monte Musarra (Floresta) (Fig. 4 a), the species also occurs in the clearings of the degraded Quercus cerris L. woods of the northern and western slopes, partly very steep, of the nearby Monte Colla (Fig. 4b). It is assumed that it can also be found in all carbonate soils (Fig. 5) above 1000 of altitude of the basins of the two rivers that originate in this area: the Alcantara and the Flascio rivers. Therefore, it is not a localized species, although its distribution area is always limited to a few hundred hectares.

The area that includes the locus classicus and the other nearby stations of C. heywoodiana falls within the potential space of deciduous oak forests of Q. cerris (Quercetalia pubescenti-petraea Klika 1933), which occupy extensive areas on the Nebrodi Mountains. In its habitat, $C$. heywoodiana grows together with Dianthus siculus C. Presl, Thymus spinulosus Ten., Brachypodium pinnatum (L.) P. Beauv., Origanum vulgare L., Eryngium campestre L., Rosa canina L., R. montana Chaix, Sternbergia sicula Tineo ex Guss., Asphodelus ramosus L. subsp. ramosus, Clinopodium nepeta (L.) Kuntze, Trifolium ochroleucon Huds., Medicago lupulina subsp. cupaniana Guss., Plantago lanceolata L., Leontodon siculus (Guss.) Nyman, Carlina nebrodensis Guss. ex DC., Cirsium vallisdemonii Lojac., Reichardia picroides (L.) Roth., Bellis margaritaefolia Huter, Porta \& Rigo, Galium verum L., Asperula cynanchica L., Verbascum sp., Helianthemum sp., Allium sp., ecc.

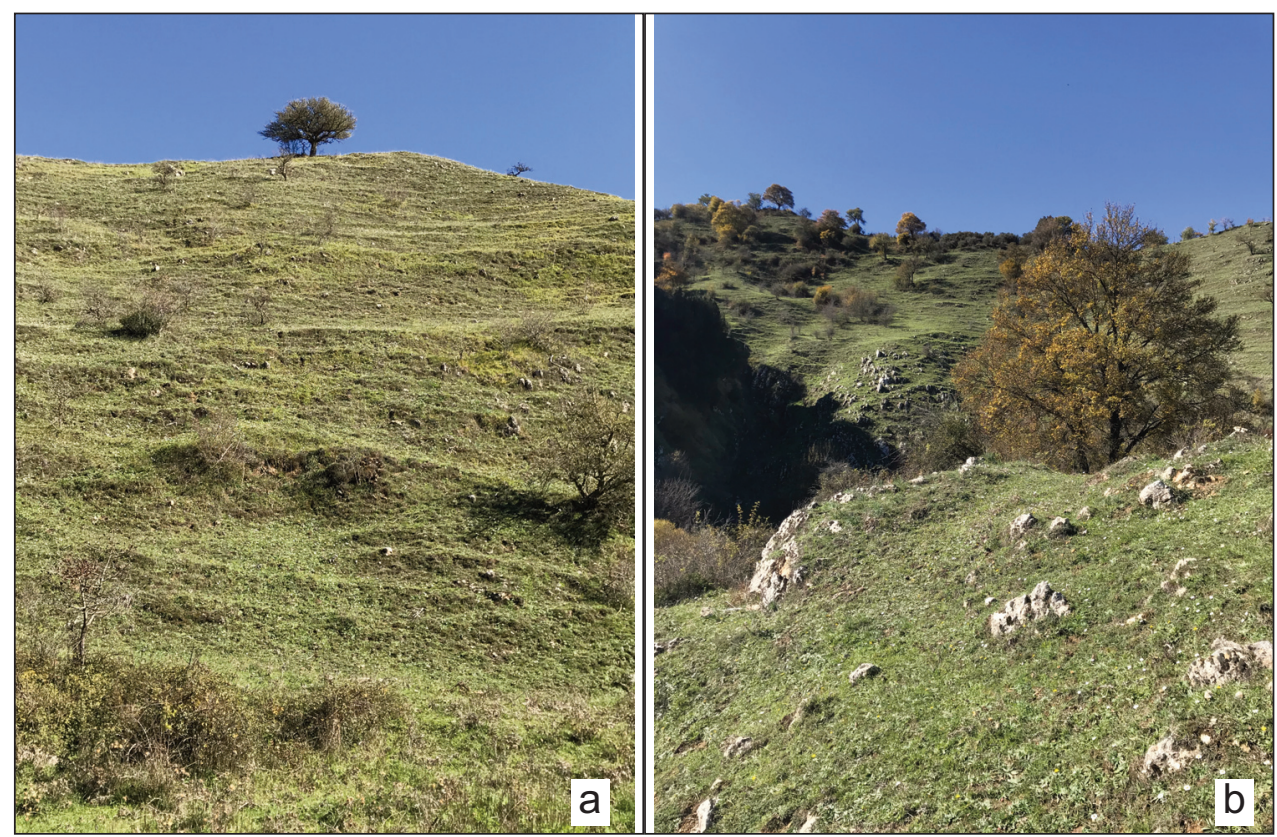

Fig. 4. The calcareous slopes of Monte Musarra, locus classicus of Centaurea heywoodiana (a); north-western slopes of Monte Colla where Centaurea heywoodiana also occurs (b). 




Fig. 5. Centaurea heywoodiana in its calcareous habitat (eastern slopes of Monte Musarra).

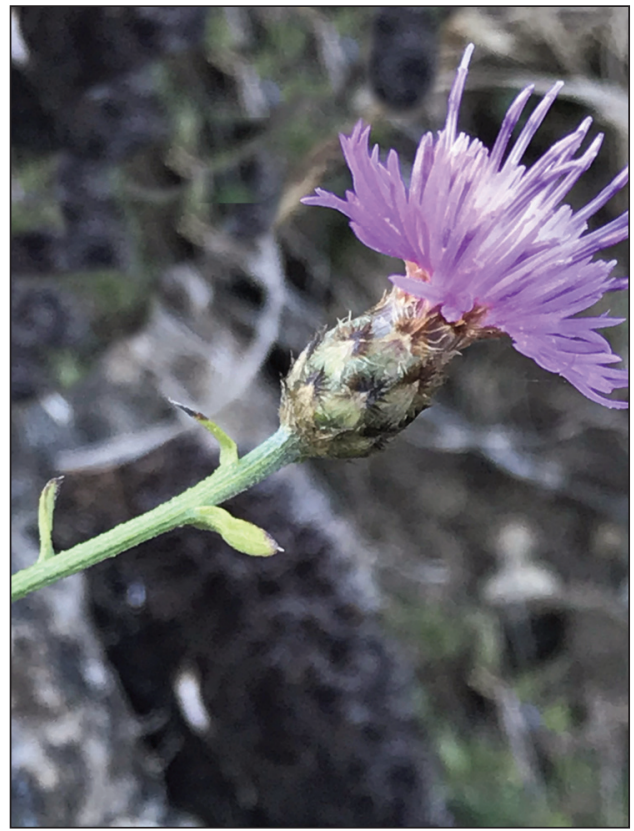

Fig. 6. Centaurea heywoodiana in flowering (photo taken on 25.07 .2020 by F.M. Raimondo): see the terminal cauline leaves, mucronate at apex.

Taxonomic remarks. - Compared to the Sicilian species of Centaurea sect. Dissectae (Hayek) Dostál, all with late spring flowering, C. heywoodiana is the only one to bloom in the middle of summer. Among all, it is a small plant, with linear and mucronate apical leaflets at the end. The capitula are very small and so is the achene. The basal leaves are short and never tomentose. For these characters it is close to C. sicana from the center of Sicily; the latter is distinguished by its erect and most scabrid stems, the much more developed cauline leaves, the larger capitula, the bracts with more numerous fimbriae and the longer achene. C. heywoodiana differs from $C$. giardinae of nearby Mount Etna, which instead of presents as a very vigorous plant, larger in size, with erect stems and undivided basal leaves; the apical ones never mucronate at the apex; larger capitula and a ribbed achene with short and thin hairs. Compared to $C$. parlatoris Heldr. and to C. gussonei Raimondo \& Spadaro (C. parlatoris var. tomentosa Guss.), both species endemic to Sicily, the differences are even more marked: moreover, $C$. gussonei - reported for the Madonie and Peloritani Mountains to Mt Scuderi (Giardina \& al. 2007 ) - is a more robust plant than $C$. parlatoris and it is entirely whitish-tomentose. Finally, for the apical leaves of the mucronate floral stem, the new species has similarities with $C$. ambigua Guss., a critical taxon whose presence in Sicily - although originally described from this island (Dostál 1976) - is excluded, and reported, instead, for the Italian peninsula (Greuter 2008; Bartolucci \& al. 2018; Pignatti 2018). 


\section{Acknowledgements}

This work was supported by "Progetto di Ricerca di Rilevante Interesse Nazionale" (PRIN) "PLAN.T.S. 2.0 - towards a renaissance of PLANt Taxonomy and systematics" lead by the University of Pisa, under the grant number 2017JW4HZK. The authors are grateful: to PLANTA (Palermo) and Agriturismo Pardo (Ucria, Messina) for the logistic support respectively in the study of the specimens and in the exploration of the Nebrodi Mountains; to the technical staff of the Nebrodi Regional Park for the assistance in the field; to Svetlana Bancheva (Sofia) and Gianniantonio Domina (Palermo) for their critical reading of the text. Finally, to Vincenzo Magro (Palermo) for the drawing of Fig. 1, and to Laura Bertini and Roberta Orlando for their precious collaboration within the PLANTA laboratory in Palermo.

\section{References}

Bartolucci, F., Peruzzi, L., Galasso, G., Albano, A., Alessandrini, A., Ardenghi, N.M.G., Astuti, G., Bacchetta, G., Ballelli, S., Banfi, E., Barberis, G., Bernardo, L., Bouvet, D., Bovio, M., Cecchi, L., Di Pietro, R., Domina, G., Fascetti, S., Fenu, G., Festi, F., Foggi, B., Gallo, L., Gottschlich, G., Gubellini, L., Iamonico, D., Iberite, M., Jiménez-Mejías, P., Lattanzi, E., Marchetti, D., Martinetto, E., Masin, R. R., Medagli, P., Passalacqua, N. G., Peccenini, S., Pennesi, R., Pierini, B., Poldini, L., Prosser, F., Raimondo, F.M., Roma-Marzio, F., Rosati, L., Santangelo, A., Scoppola, A., Scortegagna, S., Selvaggi, A., Selvi, F., Soldano, A., Stinca, A., Wagensommer, R. P., Wilhalm, T. Conti, F. 2018: An updated checklist of the vascular flora native to Italy. - Pl. Biosyst. 52(2): 179-303. https://doi.org/10.1080/11263504.2017.1419996

Brullo, C., Brullo, S., Cambria, S. \& Giusso, G. 2015: Salix nebrodensis (Salicaceae), a new species from Sicily. - Phytotaxa 218(3): 268-278. https://doi.org/10.11646/phytotaxa.218.3.5

Caldarella, O., Gianguzzi, L. \& Gottschlich, G. 2014: Hieracium busambarense, a new species of the sect. Grovesiana (Asteraceae) from Sicily (Italy). - P1. Biosyst. 148(3): 439-443. https://doi.org/10.1080/11263504.2013.778352

Costa, R. S. M. \& Di Gristina, E. 2020: Xeranthemum cylindraceum (Asteraceae) in Italy: first record for the Sicilian flora. - Fl. Medit. 30: 235-243. https://doi.org/10.7320/FlMedit30.235

Di Gristina, E., Gottschlich, G. \& Raimondo, F. M. 2016a Rediscovery of Hieracium nebrodense (Asteraceae), a little-known endemic of Sicily (Italy). - Phytotaxa 265(1): 59-66. https://doi.org/10.11646/phytotaxa.265.1.5

—, — \& - 2016b: Pilosella hoppeana subsp. sicula Di Grist., Gottschl. \& Raimondo (Asteraceae), a new endemic subspecies from Sicily (Italy). - Candollea 71(1): 7-12. https://doi.org/10.15553/c2016v711a2

—, - Galesi, R., Raimondo, F. M. \& Cristaudo, A. 2013: Hieracium hypochoeroides subsp. montis-scuderii (Asteraceae), a new endemic subspecies from Sicily (Italy). - Fl. Medit. 23: 4955. http://dx.doi:10.7320/FlMedit23.049

Domina, G., Greuter, W. \& Raimondo, F. M. 2017: A taxonomic reassessment of the Centaurea busambarensis complex (Compositae, Cardueae), with description of a new species from the Egadi Islands (W Sicily). - Israel J. Pl. Sci. 64(1-2): 48-56. https://doi.org/10.1080/ 07929978.2016.1257146

—, Venturella, G. \& Gargano, M. L. 2018: Synthetic cartography for mapping biodiversity in the Mediterranean region: Sicily as a case study. - PhytoKeys 109: 77-92. https://doi.org/10.3897/phytokeys.109.28297

Dostál, J. 1976: Centaurea L. - Pp. 254-301 in: Tutin, T. G., Heywood, V. H., Burges, N. A., Moore, D. M., Valentine, D. H., Walters, S.M. \& Webb, D. A. (eds), Flora Europaea 4. - Cambridge. 
Gottschlich, G., Raimondo, F. M. \& Di Gristina, E. 2013: Hieracium pallidum subsp. aetnense (Asteraceae), a new subspecies from Sicily (Italy), with notes on the taxonomy of H. pallidum Biv. - Pl. Biosyst. 147(3): 826-831. https://doi.org/10.1080/11263504.2013.829882

Greuter, W. 2008: Dicotyledones (Compositae). In: Greuter, W. \& Raab-Straube (von), E. (eds), Med-Checklist, 2. - Palermo.

Guarino, R., Raimondo, F. M. \& Domina, G. 2013: A new species of Anthemis sect. Hiorthia (Asteraceae) from SE Sicily. - Pl. Biosyst. 147(3): 821-825. http://dx.doi.org/10.1080/11263504.2013.82988

Marino, P., Castellano, G., Spadaro, V. \& Raimondo, F. M. 2012: Pyrus ciancioi (Rosaceae), a new species from Sicily. $\quad-\quad$ Pl. Biosyst. 146(3): 654-657. http://dx.doi.org/10.1080/11263504.2012.700960

Peruzzi, L., Aquaro, G., Caparelli K. F. \& Raimondo F. M. 2009: The genus Taraxacum (Asteraceae) in Italy. III. A new species of $T$. sect. Erythrocarpa from Sicily. - Fl. Medit. 19: 73-79.

Pignatti, S. 2018: Flora d'Italia, 2a ed., 3. - Milano.

Raimondo, F. M. 1988: Stato delle conoscenze floristiche della Sicilia al 1987. - Pp. 637-665 in: Pedrotti F. (ed.), 100 anni di ricerche botaniche in Italia: 1888-1988, 2. - Firenze.

— 2008: A new species of Malus (Rosaceae, Maloideae) from Sicily. - Fl. Medit. 18: 5-10.

— \& Bancheva, S. T. 2004: Centaurea erycina (Asteraceae), a new species from NW-Sicily. Bocconea 17: 299-306.

— \& Di Gristina, E. 2004: Hieracium pignattianum (Asteraceae), a new species from the Madonie Mountains (N-Sicily). - Bocconea 17: 313-324.

— \& - 2007: Hieracium madoniense (Asteraceae), a new species from Sicily. - Pl. Biosyst. 141(1): 86-92. https://doi.org/10.1080/11263500601153982

— \& Schicchi R. 2004: Pyrus vallis-demonis (Rosaceae), a new species from the Nebrodi Mountains (NE-Sicily). - Bocconea 17: 325-330.

— \& Spadaro, V. 2006: Una nuova specie di Centaurea (Asteraceae) dell'Etna (Sicilia orientale). Naturalista Sicil., s.4, 30(4): 371-378.

— \& - 2008: A new species of Centaurea (Asteraceae) from Sicily. - Bot. J. Linn. Soc. 157(4):

785-788. https://doi.org/10.1111/j.1095-8339.2008.00813.x

-, Bancheva, S. T. \& Ilardi, V. 2004: Centaurea saccensis (Asteraceae), a new species from SW Sicily. - Bocconea 17: 293-298.

-, Domina, G. \& Bazan, G. 2005: Carta dello stato delle conoscenze floristiche della Sicilia. - Pp. 203-207 in: Scoppola, A. \& Blasi, C. (eds), Stato delle Conoscenze sulla Flora Vascolare d'Italia. - Roma.

Addresses of the authors:

Francesco Maria Raimondo1, Vivienne Spadaro² \& Emilio Di Gristina ${ }^{3 *}$,

${ }^{1}$ Francesco Maria Raimondo, PLANTA/ Center for Research, Documentation and Training, Via Serraglio Vecchio 28, 90123 Palermo, Italy. E-mail: raimondo@centroplantapalermo.org

${ }^{2}$ Vivienne Spadaro, Department STEBICEF/Section of Botany, Anthropology and Zoology, University of Palermo, Via Archirafi 38, 90123 Palermo, Italy. E-mail: vivienne.spadaro@unipa.it

${ }^{3}$ Department of Agricultural, Food and Forest Sciences (SAAF), University of Palermo, Viale delle Scienze, bld. 4, 90128 Palermo, Italy. E-mail: emilio.digristina@unipa.it

*Corresponding author 